\title{
Os fluxos de migrações internacionais e as fronteiras impermeáveis: abordagem crítica às restrições ao processo de migrações voluntárias*
}

\section{Resumo}

Este artigo analisa o fenômeno dos fluxos migratórios internacionais, bem como das normas internacionais existentes para a proteção das pessoas. É demonstrado, de forma sucinta, o surgimento e evolução dessas normas componentes do sistema global de proteção dos direitos da pessoa humana. Do mesmo modo, é analisado o tratamento regional da matéria em dois blocos de integração econômica: Mercosul e União Europeia, os quais por essência, deveriam facilitar o movimento de livre circulação de pessoas. Numa perspectiva crítica, são propostas novas formas de abordagens para o tema, uma reflexão sobre o insuficiente nível de proteção internacional que têm recebido os migrantes.

Palavras-chave: Migrações internacionais. Direitos dos migrantes. Organizações internacionais. Blocos de integração.

* Recebido em 06.03.2012

1 Professora Universitária. Mestre em Direito Internacional na UFMG. Doutoranda em Relações Internacionais pela UnB. Especialista Técnico do Ministério do Desenvolvimento, Indústria e Comércio Exterior. Atualmente trabalha com negociações internacionais no DEINT (Departamento de Negociações Internacionais) da SECEX (Secretaria de Comércio Exterior). Email: blenda.fonseca@mdic.gov.br 


\section{Introdução}

As migrações, ao largo tempo, têm sido uma grande preocupação na ordem mundial. ${ }^{2}$ Em função dos esforços que lograram apenas uma codificação internacional insuficiente e pouco aceita pelos Estados, o então Secretário Geral da Organização das Nações Unidas (ONU), Kofi Annan, incentivou a criação de uma Comissão Mundial sobre Migrações Internacionais ${ }^{3}$ no ano de 2003. Desde a publicação do relatório dessa Comissão, em 2005, a situação dos refugiados e migrantes no planeta não mudou muito (GLOBAL COMMISSION ON INTERNATIONAL MIGRATION, 2005).

Migrante é "qualquer pessoa que mude de seu país de residência usual", consistindo um critério geográfico que desconsidera a motivação para o ato de migrar. Dentro desse conceito, cabem outros como o de refugiado ou asilado. O refugiado é um tipo específico de migrante, aquele que migra em função de um bem fundado temor de perseguição por motivos de nacionalidade, política ou raça.

As novas tecnologias permitem rápida transferência de diversos bens materiais e imateriais pelo globo. Nem sempre os agentes dessa transferência são físicos ou humanos, e muitos operam em rede (network), ou seja, de modo integrado. Talvez por isso, desenvolveu-se em menor grau o interesse pela regulamentação da transferência de pessoas, se comparado às transações de mercadorias. Há que se considerar que “[...] os avanços na comunicação e no transporte facilitaram os movimentos migratórios e a transferência de informação e dinheiro, mas criaram novas ameaças à segurança humana, que demandam estratégias particulares" (VARESE et. al., 2008, p.).

Todas essas modificações relacionadas à globalização levaram a uma mudança na estrutura dos fluxos migratórios.

2 O número de migrantes internacionais dobrou de 75 milhões para 200 milhões nos últimos 30 anos. Fonte: NEW DELHI ONLINE. Migration Doubled To 200 Mn In 30 Years. Disponível em:. <http://www.gcim.org/mm/File/BS\%20Migration \%20Doubled\%20to\%20200\%20Mn\%20in\%2030\%20 Years(4).pdf $>$. Acesso em: 16 nov. 2008.

3 Foi estabelecida por um Grupo Central de Estados que, em agosto de 2005, incluía os seguintes governos: Argélia, Austrália, Finlândia, França, Alemanha, Santa Sé, Hungria, Índia, Indonésia, República Islâmica do Irã, Japão, México, Marrocos, Países Baixos, Nigéria, Noruega, Paquistão, Peru, Filipinas, Federação Russa, África do Sul, Espanha, Sri Lanka, Suécia, Suíça, Turquia, Reino Unido e União Europeia.
Pesquisas descobriram que movimentos temporários e migrações irregulares são os padrões que crescem mais rápido nas migrações, notamos a feminização da migração, talvez seja mais adequado dizer, feminização da pesquisa; observamos o retorno de um espaço de migração europeu, o reavivamento de alguns padrões tradicionais na Ásia Central e através do Sahara e a insurgência de mercados de trabalho globais facilitando as migrações globais. Ao mesmo tempo, migrantes originam-se de qualquer parte do mundo e podem ser encontrados em qualquer parte do mundo, ilustrando a crescente globalização da imigração. (DUVELL, 2006, p. 5, grifo nosso).

Essas mudanças provocaram impacto nos fluxos migratórios e um incremento no debate a respeito da proteção cabível e devida. Ocorre que os Estados, ao tentarem exercer seu legítimo direito westfaliano de proteger suas fronteiras, estão a ignorar a ampla aplicação do art. 14 da Declaração Universal de Direitos Humanos, a qual consagra o direito de asilo. ${ }^{4}$

Atualmente, há diversos desafios que cercam as migrações internacionais, dentre os quais se destaca a necessidade de proteção adequada aos grupos humanos que compõem os chamados fluxos mistos, ou seja, fluxos migratórios compostos por migrantes e indivíduos perseguidos (possíveis solicitantes do status de refugiado), ${ }^{5}$ a necessidade de um trabalho concertado para impedir a ação de traficantes de pessoas, os quais se valem da situação de fragilidade de alguns para lucrar; e de definição de um programa de migração concertado, com quotas, evitando a ação imigratória irregular.

A gestão das migrações e a proteção dos refugiados são atividades distintas, porém complementares. A resposta a esse fenômeno está na coo-

\footnotetext{
4 Declaração Universal de Direitos Humanos, art. 14: “1 - Toda pessoa sujeita a perseguição tem o direito de procurar e de beneficiar de asilo em outros países. 2 - Este direito não pode, porém, ser invocado no caso de processo realmente existente por crime de direito comum ou por atividades contrárias aos fins e aos princípios das Nações Unidas".

5 Este artigo apenas terá por objeto os migrantes internacionais em seu sentido estrito, tangenciando em alguns pontos a especificidade da questão dos refugiados. Deve-se guardar em mente que a "migração e a proteção de refugiados são temas distintos, as complementares" Cf.: MURILLO, Juan Carlos. A proteção internacional dos refugiados na América Latina e o tratamento dos fluxos migratórios mistos. Caderno de Debates Refúgio, Migrações e Cidadania, Brasília, v. 3, n. 3, p. 25-30, 2008. Para responder aos fluxos migratórios mistos, em abril de 2006, o ACNUR compartilhou com os Estados, por meio de um "Plano de Ação de 10 Pontos", sua estratégia de ação (MURILLO 2008, p. 28).
} 
peração pelo desenvolvimento, numa melhor distribuição da riqueza gerada pela globalização e na promoção da inclusão social e da tolerância com todos que buscam uma nova vida fora de seu país de origem (VARESE et. al., 2008, p. 12 ).

Interessa notar que o discurso brasileiro é no sentido de aproximar a proteção dos migrantes à proteção genérica relativa aos direitos humanos. Os países relutam a tal reconhecimento, muito em razão da pressão da opinião pública interna, sempre suspeita ao elemento alienígena.

Alguns governos admitem números consideráveis de migrantes no seu país, mas não investem depois no processo de integração que é necessário para que essas pessoas desenvolvam o seu potencial e possam dar um contributo positivo à sua nova sociedade (GLOBAL COMMISSION ON INTERNATIONAL MIGRATION, 2005).

Dentre os aspectos positivos da imigração, especialmente os "ganhos humanos", citam-se: (i) o incremento de capacitação do imigrante quando trabalha no estrangeiro, o que o faz, por vezes, regressar próspero; (ii) requerentes de refúgio que escapam à perseguição e conseguem segurança, (iii) a integração de comunidades inteiras de migrantes ao país receptor, sem que com isso percam sua identidade original; e (iv) o sentimento de solidariedade gerado na sociedade.

Os países desenvolvidos também se valem do processo de migração. Considerando que é evidente o envelhecimento de sua população, por conseguinte, em breve estará presente a dificuldade em manter os níveis atuais de produtividade econômica, em suportar os sistemas de pensões e seguridade social e em encontrar pessoas habilitadas a assistir a população idosa.

\begin{abstract}
As migrações têm sido uma característica constante e influente na história da humanidade. Tem apoiado o processo de crescimento econômico mundial, contribuído para a evolução dos Estados e das sociedades e enriquecido muitas culturas e civilizações (GLOBAL COMMISSION ON INTERNATIONAL MIGRATION, 2005, p.5).
\end{abstract}

No mundo atual, as migrações internacionais continuam a ter um papel importante nos assuntos nacionais e regionais. Especialmente no âmbito financeiro, suas vantagens foram comprovadas, seja pelo Fundo Monetário Internacional (FMI), ou pelos dados aferidos pelos Estados, no que tange às remessas de nacionais no exterior a seu local de origem. Essas remessas melhoram o nível de vida das famílias dos migrantes e são fonte de capital para o estabelecimento de pequenos negócios (GLOBAL COMMISSION ON INTERNATIONAL MIGRATION, 2005).

Embora as políticas de migração, para se tornarem exitosas, devem basear-se em objetivos partilhados, não há um consenso quanto à introdução de um sistema formal de governança a nível mundial para as migrações internacionais. Talvez seja esse o grande desafio a ser enfrentado pelos Estados.

Alguns incidentes ligados à imigração e/ou imigrantes, tais como deportações em massa, cometimento de ilícitos e atos terroristas por estrangeiros, levaram os Estados a realizar uma maior fiscalização de suas fronteiras. Em razão dos fatos citados, alguns estadistas pensam que a imigração irregular seja uma ameaça à soberania e à segurança estatais. Apesar dos incidentes, os quais eventualmente ocorrem, é preciso reconhecer o contributo que os migrantes conferem tanto à nova comunidade na qual se inserem, como à comunidade de origem.

Nesse sentido, esse ensaio buscará apresentar, em um primeiro momento, os conceitos cruciais relativos às migrações e, posteriormente, o desenvolvimento da proteção do migrante no plano internacional, por intermédio de instrumentos normativos e instituições com mandatos específicos relacionados à temática da migração. Por fim, será analisada a relação dos fluxos migratórios com os blocos de integração econômica, em especial a abordagem limitada da livre circulação de pessoas.

\section{Os fenômenos migratórios internacionais}

No passado, era mais fácil transitar entre diferentes nações. Com o estabelecimento mais rígido do controle das fronteiras, iniciaram-se maiores obstáculos para um indivíduo migrar de um país a outro. No começo do século XIX, a imigração reduzia-se aos casos de tráfico de escravos, uma migração forçada, e aos colonos que viajavam em busca de conquistas em uma nova terra. "Ao fim do século 19, os mercados de trabalho eram mais globalizados que são hoje” (O’ROURKE et. al., 2004, p.11).

As barreiras contra imigração começaram a ser erigidas nesse período - fim do século XIX -, não obstante esse período seja ainda marcado pela liberalização. A queda dos custos de transporte levou a um grande fluxo migratório, especialmente dos europeus, que se des- 
tinavam ao "novo mundo" (entre 1820-1914). As razões para o fechamento das fronteiras, mesmo nesses novos espaços geográficos, relacionam-se com um fator físico: o governo não foi mais capaz de lidar com populações crescentes apenas aumentando o tamanho das terras cultiváveis. De forma característica, os imigrantes dessa época eram tipicamente jovens e adultos (entre 15 e 40 anos), em sua maioria, e não possuíam muitas qualificações em razão de falta de oportunidades em seu país de origem. "De fato, com o decorrer do século, os migrantes tornaram-se cada vez menos qualificados, a cada vez que a fonte de imigração européia voltava-se para o sul e o leste" (O’ROURKE et. al., 2004, p.14). Esse fato implicou a queda dos salários dos migrantes no país de destino.

A história da migração não testemunhou a criação de uma organização internacional para liberar os fluxos migratórios, tal como ocorreu com as mercadorias, cuja liberação encontrou inicialmente moldura jurídica no Acordo Geral de Comércio e Tarifas (em inglês, GATT), e posteriormente, na Organização Mundial do Comércio (OMC), que abrangeu também os serviços. Registre-se que foi proposto que a Organização Internacional do Trabalho (OIT) cumulasse também a função de regular os fluxos de pessoas. Todavia, com o desacordo dos países desenvolvidos a esse respeito, o controle da imigração ficou a cargo dos Estados individualmente.

Ao não conseguir acesso a meios de subsistência, algumas pessoas decidem migrar para encontrar oportunidades de emprego no exterior. Esses indivíduos ficam sujeitos a toda sorte de exploração. Nas palavras do Diretor-Geral da OIT: “[...] a crise mundial de empregos está a colocar em risco a segurança, o desenvolvimento, as economias abertas e as sociedades abertas. Este curso dos acontecimentos não é sustentável” (GLOBAL COMMISSION ON INTERNATIONAL MIGRATION, 2005, p.11). Mas, as dificuldades para migrar são encontradas tanto por trabalhadores qualificados, quantos desqualificados; a diferença principal é que estes últimos, pela necessidade, utilizam a todo custo a via irregular.

Não são apenas os fatores econômicos as principais causas das migrações. Em verdade, as três principais causas são as diferenças existentes entre os países em termos de níveis de desenvolvimento, demografia e consolidação democrática. Os motivos econômicos ficam claros ao se considerar que os países em desenvolvimento, apesar do esforço hercúleo feito nos últimos anos, não conseguiram criar empregos suficientes para absorver um excedente de mão de obra, nem sempre qualificada. Tal situação é reconhecida por alguns países, que chegam a adotar políticas governamentais tendentes a facilitar a emigração dos seus cidadãos, de modo a reduzir os níveis de desemprego ${ }^{6}$ e aumentar o volume de remessas para o país de origem (GLOBAL COMMISSION ON INTERNATIONAL MIGRATION, 2005, p. 11). Por outro lado, restrições de direitos, especialmente de participação política, podem levar a processos migratórios. No caso cubano, por exemplo, há um misto de opressão política com restrições econômicas. ${ }^{7}$

As migrações internacionais implicam o deslocamento do indivíduo entre duas ou mais unidades politicamente organizadas. "Migração é todo movimento 'espontâneo’ e de caráter voluntário, podendo ser documentado ou irregular" (GREGORI, 2007, p.18). De acordo com recomendação da ONU a respeito da temática, um migrante internacional é definido como "[...] qualquer pessoa que mude de seu país de residência usual” (HAKIM et. al., 2004, p. 24). A definição é censitária: foca-se um elemento geográfico com o fito de distinguir com clareza o mero visitante daquele que é parte da população do Estado (cidadão ou não).

Além disso, a ONU distingue entre visitantes, migrantes por curto período (mais de três meses e menos de um ano de permanência, além do exercício de atividade econômica remunerada), migrantes por longo período (permanência de pelo menos um ano) e os migrantes

${ }_{6}$ Desse contingente de itinerantes, as mulheres têm sido expressivo número. Expostas a maiores riscos, cada vez mais emigram sozinhas e constituem a principal fonte de rendimento das famílias que ficam no país de origem. O mercado de trabalho aos quais se direcionam são exatamente o trabalho doméstico, a enfermagem e serviços de cuidados pessoais, limpezas em geral, entretenimento e comércio sexual. Nesse sentido, vide: GLOBAL COMMISSION ON INTERNATIONAL MIGRATION. Migration in an interconnected world: new directions for action. 2005. Disponível em: <http:// www.gcim.org/en/finalreport.html $>$. Acesso em: 28 maio 2008.

7 Em setembro de 2007, o Brasil concedeu status de refugiado aos cubanos desportistas (o jogador de handebol Rafael D’Acosta Capote e ao ciclista Michel Fernández García), que desertaram da delegação de seu país durante os jogos pan-americanos. Em 2008, três músicos de um conjunto cubano em turnê pelo estado brasileiro de Pernambuco (os músicos Miguel Angel Costafreda, Arodis Verdecia Pompa e Juán Alcides Diaz) pediram, igualmente, reconhecimento do status de refugiado, o que foi concedido pela autoridade brasileira. 
permanentes (possuem permissão para se estabelecer por tempo maior, sem limitações para o exercício de atividade econômica). Todavia, poucos Estados aceitaram essas definições (HAKIM et. al., 2004). E é justamente essa falta de uniformidade de definição que dificulta a criação de estatísticas seguras no plano internacional acerca dos fluxos migratórios, bem como o estabelecimento de políticas internacionais direcionadas aos migrantes.

Conceituar o termo migrante é tarefa de alta complexidade, ${ }^{8}$ uma vez que persistem diversas motivações (desde questões financeiras, opressão política, profissionais, catástrofes naturais, perseguições aos conflitos armados), e os casos de migração padecem de uma tipicidade regular. Alguns diferenciam entre os migrantes regulares e aqueles irregulares, os trabalhadores qualificados e aqueles não qualificados, ou ainda, os residentes permanentes e aqueles temporários. Além dessas denominações clássicas, também os migrantes que se deslocam por outras razões, entre as quais a busca da reunião familiar, para fins de estudo ou por mero trânsito.

Diante da diversidade, uma política de migrações coerente e completa deveria contemplar as circunstâncias específicas de cada um desses grupos, ou não conseguiria fazer jus à complexidade das migrações internacionais.

Na doutrina, as variáveis "vulnerabilidade" e "risco" são suficientes para distinguir os tipos de migrantes, inter alia, migrantes de origem, migrantes de trânsito, migrantes de destino e migrantes de reunião familiar (SABATES-WHEELER et. al., 2003, p.12). As determinantes da vulnerabilidade podem ser de ordem espacial, sociopolítica ou cultural, sendo cada qual um fator distinto, dependendo da categoria de migrante considerado.

Mas, por certo, o conceito de migrante, em termos específicos, vai ser encontrado à luz das definições de nacionalidade e cidadania, as quais são utilizadas como parâmetros para a determinação do status daqueles que migram (RUHS et. al., 2006, p.6). De fato, ao determinar

\footnotetext{
8 A União Soviética, em razão de suas peculiaridades sociológicas e históricas, viu nascer uma verdadeira cultura de movimento migratório, com conceitos próprios, tais como "povos anteriormente deportados", "migrantes ecológicos", "reinstalação involuntária de pessoas" e "migrantes em trânsito". Cf. DÜVELL, Franck. Questioning conventional migration concepts: the case of transit migration. Disponível em $<\mathrm{http}: / /$ www.compas.ox.ac.uk/publications/papers/2006-06-21-Duvell-Budapest.pdf>. Acesso em: 27 jul. 2008. p.9.
}

o status de nacional, o Estado estabelece o limite da sua jurisdição e controla suas fronteiras. No Brasil, a Constituição Federal em seu art. 12 define o nacional brasileiro baseado no critério do ius soli (nascimento em solo), fazendo exceção em alguns casos para o critério do ius sanguinis (critério de filiação). Em sede infraconstitucional, a Lei n. 6.815/81 - o Estatuto do Estrangeiro - trará mais disposições a respeito, inclusive ditando direitos, vedações e punições ao estrangeiro em território nacional. Muito criticado em razão de ser da época ditatorial, tentou-se uma modificação da legislação, que, todavia, ainda não foi substituída.

Assim como toda legislação interna a respeito de estrangeiros, a brasileira faz menção à entrada regular ou irregular em seu território, punindo o estrangeiro com medida administrativa de deportação em caso de desrespeito aos seus ditames. O Brasil segue na linha da maior parte dos países que não considera a imigração irregular um crime, podendo o estrangeiro irregular retornar tão logo deseje e tenha reabilitado sua situação, além de pagos os gastos com a medida administrativa. ${ }^{9}$

\footnotetext{
9 Consoante à legislação brasileira, Lei 6.815/80, vulgo Estatuto do Estrangeiro, há diferenças significativas entre as medidas compulsórias de expulsão e deportação. O artigo56 reza que ocorrerá deportação para o estrangeiro que entrar ou permanecer irregular no território brasileiro, se ele não se retirar voluntariamente no prazo fixado em regulamento governamental. Essa irregularidade de permanência ou entrada ocorre em razão de estar o estrangeiro com o visto ou passaporte vencidos, por haver entrado sem visto no país ou nele ter permanecido após seu vencimento. Da mesma forma, será deportado o estrangeiro que incorrer em prática de atividade remunerada, desde que tal não seja permitido pela espécie de visto que fora solicitado. Ao contrário do estrangeiro expulso, o deportado pode retornar ao país contanto que regularize sua situação e/ou arque com as despesas de sua eventual deportação. O estrangeiro será expulso se atentar contra a segurança acional, a ordem política ou social, a tranqüilidade ou moralidade pública e a economia popular, ou que tenha procedimento nocivo à conveniência e aos interesses nacionais (artigo 65). O estrangeiro expulso não pode retornar, a menos que seja revogado o decreto que determinou sua expulsão. Em razão disso, há impeditivos para a expulsão: estrangeiro casado com brasileiro (a) há mais de cinco anos, estrangeiro que tenha filho brasileiro sob sua guarda ou dependência econômica (artigo 75).
} 


\section{Desenvolvimentos no plano internacional para a construção de uma proteção normati- va ao migrante}

As normas internacionais que regulamentam a proteção dos migrantes são compostas pelo Direito consuetudinário e tratados regionais e universais, além de outros instrumentos que refletem o conceito de soft law. ${ }^{10}$ Há também, não obstante a ausência de efeitos jurídicos vinculantes, entendimentos políticos a respeito da matéria. A maior parte dos textos relacionados não é específica para as migrações; há, sim, instrumentos internacionais, os quais aplicados à época atual abarcam uma enormidade de situações a respeito de direitos humanos. Todavia, salienta-se que o principal obstáculo à proteção dos migrantes não é a ausência de normas, mas o fato de que alguns Estados não respeitam as convenções existentes.

Os instrumentos gerais a respeito da matéria são: a Carta da ONU, a Declaração Universal dos Direitos Humanos, algumas Convenções do Trabalho da OIT, ${ }^{11}$ Convenção Relativa ao Estatuto dos Refugiados (Convenção de 1951) e o seu Protocolo de 1967 e a Convenção de Viena sobre Relações Consulares de 1963. Além desses, citam-se o Protocolo para Prevenir, Suprimir e Punir o Tráfico de Pessoas, especialmente Mulheres e Crianças

10 "O conceito de soft law emergiu a partir da relevância e da atuação crescente da diplomacia multilateral, seja nos foros diplomáticos de negociações, seja a partir de interpretações dadas aos tratados multilaterais elaborados sob a égide das organizações intergovernamentais, seja dos próprios atos unilaterais destas, seja nas organizações intergovernamentais, seja em congressos e conferências." (SOARES, 2002, p.137). Ganhou ênfase tal conceito a partir da emergência dos novos temas de Direito Internacional após a década de 1960, encontrando amplo espaço nas conferências internacionais, locais em que nem sempre os diplomatas estiveram preocupados com a "roupagem jurídica" de suas decisões, dada a necessidade de que as mesmas se dessem de forma célere e eficaz. Em geral, tais normas tomam corpo como non biding agreements, gentlemen's agreements, códigos de conduta, memorandos, declaração conjunta, declaração de princípios, ata final e alguns acordos e protocolos. Para mais, ver SOARES, Guido Fernando Silva. Curso de direito internacional público. São Paulo: Atlas, 2002. p.137.

${ }^{11}$ Especialmente as convenções: Convenção relativa aos Trabalhadores Migrantes (n. ${ }^{\circ}$ 97), Convenção relativa às Migrações em Condições Abusivas e à Promoção da Igualdade de Oportunidades e de Tratamento dos Trabalhadores Migrantes (n. ${ }^{\circ}$ 143), a Recomendação relativa à Migração para o Emprego (n. $\left.{ }^{\circ} 86\right)$, a Recomendação relativa aos Trabalhadores Migrantes (n. $\left.{ }^{\circ} 151\right)$, a Convenção sobre Trabalho Forçado ou Obrigatório (n. $\left.{ }^{\circ} 29\right)$ e a Convenção sobre a Abolição do Trabalho Forçado (n. ${ }^{\circ}$ 105). (adotado em 2000, e em vigor desde 2003), e o Protocolo contra o Contrabando de Migrantes por Terra, Mar e Ar (adotado em 2000, e em vigor desde 2004), ambos relativos à Convenção da ONU contra o Crime Transnacional Organizado (adotada em 2000, e em vigor desde 2003).

Ademais, dentre os tratados reputados pela ONU como "tratados essenciais de direitos humanos", estão os que salvaguardam os direitos das crianças, mulheres e trabalhadores migrantes. ${ }^{12}$

Antes da explanação das normas, cabe ressaltar que a estada ou entrada irregular em um dado país não priva o indivíduo de direitos humanos básicos, assim como não retira o dever do Estado de proteger os migrantes em situação irregular. Esse reconhecimento de direitos humanos mínimos embasa casos tais como o do brasileiro Jean Charles de Menezes, executado sumariamente por policiais londrinos.

\subsection{A declaração universal de direitos humanos: pe- dra fundamental da proteção aos migrantes}

Em 2008, comemorou-se o sexagenário de aprovação do texto da Declaração Universal de Direitos Humanos (DUDH). A par de muitas conquistas ainda por vir, a beleza e efetividade desse texto normativo ao longo de todos estes anos é algo rememorado pelos defensores dos direitos da humanidade. Direitos de humanidade porque, muito mais que direitos dos homens, são hoje entendidos como direitos de solidariedade e como uma conquista da humanidade em seu conjunto (BENEVIDES, 2010).

$\mathrm{O}$ art. $1^{\circ}$ do referido texto exala os princípios axiológicos componentes do sistema universal de proteção de direitos humanos. Esta tríade fundamental (liber-

\footnotetext{
${ }^{12}$ Cumpre lembrar ainda outros instrumentos internacionais, os quais, ainda que de forma genérica, também trazem proteção aos migrantes: o Pacto Internacional sobre os Direitos Econômicos, Sociais e Culturais, o Pacto Internacional sobre os Direitos Civis e Políticos, a Convenção Internacional sobre a Eliminação de Todas as Formas de Discriminação Racial, a Convenção sobre a Eliminação de Todas as Formas de Discriminação contra as Mulheres e a Convenção sobre os Direitos da Criança, Convenção relativa à Luta contra a Discriminação no Campo do Ensino, da Organização das Nações Unidas para a Educação, a Ciência e a Cultura (UNESCO); a Convenção contra a Tortura e Outras Penas ou Tratamentos Cruéis, Desumanos ou Degradantes; a Declaração do Quarto Congresso das Nações Unidas para a Prevenção do Crime e o Tratamento dos Delinqüentes; o Código de Conduta para os Funcionários Responsáveis pela Aplicação da Lei; e as Convenções sobre a Escravatura.
} 
dade, igualdade e fraternidade), herança dos revolucionários franceses, ${ }^{13}$ consolidou-se no plano internacional tardiamente.

O princípio de solidariedade (ou fraternidade, como nasceu em sua origem durante a Revolução Francesa) prende-se à ideia de responsabilidade de todos pelas carências ou necessidades de qualquer indivíduo ou grupo social. Em verdade, esse princípio reflete os chamados direitos de terceira dimensão. Os direitos de solidariedade foram esboçados no artigo 28 da Declaração Universal de Direitos Humanos. Atualmente, a terceira dimensão de direitos inclui os seguintes: o direito ao desenvolvimento, à paz e ao meio ambiente (PIOVESAN, 1998, p. 28), ou seja, o direito de participar e beneficiar-se da "herança comum da humanidade".

Considerando que os migrantes estão em situação de fragilidade social, trata-se de um dever de solidariedade internacional dar a devida guarida aos migrantes regulares, bem como o condizente tratamento aos migrantes irregulares, cuja migração dá-se por razões impositivas (muito embora em caráter financeiro) que os forçam a tomar a decisão de pôr em risco suas vidas em travessias, por vezes, transcontinentais, em busca de um melhor nível de vida. É este o espírito indicado pelo art. $1^{\circ}$ da DUDH “Todas as pessoas [...] devem agir em relação umas às outras com espírito de fraternidade". ${ }^{14}$

Interessa notar o art. $6^{\circ}$ da DUDH, o qual assegura que toda pessoa, independentemente da nacionalidade, tem o direito de ser reconhecida como pessoa perante a lei. Tal indica que submeter qualquer migrante, seja ele regular ou irregular, a tratamentos desumanos ou indevidos é uma violação a esta norma.
O caráter de jus cogens ${ }^{15}$ do Direito Internacional dos Direitos Humanos é ressaltado, uma vez que todo ser humano tem certos direitos que decorrem de sua inerente dignidade apenas em virtude de sua humanidade. Isso faz com que tais direitos sejam irrenunciáveis e inalienáveis.

$\mathrm{O}$ art. $7^{\circ}$ da DUDH estabelece o direito de igualdade que todos têm perante a lei, inclusive os estrangeiros quando em trânsito ou residentes no território de outro país. Refuta esse artigo a discriminação de qualquer natureza e é complementado pelos artigos $8^{\circ}$ e 10 que falam do direito de ampla defesa e acesso à justiça, assegurando garantias processuais mínimas. Ressalte-se que o art. 10 cita a proibição de prisão arbitrária, algo frequente em relação aos migrantes irregulares.

As garantias a respeito de pleno emprego, remuneração justa e padrão de vida digno também são aplicáveis independentemente da nacionalidade, tocando igualmente os migrantes (art. 23 e 25).

Como ponto culminante, ao final da DUDH, há referência aos direitos de solidariedade, enfatizando que toda pessoa faz jus, independentemente da nacionalidade, a uma ordem social e internacional em que os direitos humanos possam ser plenamente realizados (art. 28). Ressalta, por outro lado, os deveres individuais para com essa sociedade que cria a possibilidade de expansão de sua personalidade (art. 29).

\footnotetext{
${ }^{15} \mathrm{Na}$ segunda metade do século XX, emergiram considerações sobre dois pólos normativos diferenciados dentro do corpo de normas do Direito Internacional. O primeiro, constituído por normas superiores, relativamente imutáveis, o jus cogens; já o segundo, seriam outras normas, de alguma forma subordinadas àquelas, que constituiriam o que passou a ser denominado de jus dipositivum. Em Parecer Consultivo "Reservations to the Convention on the Prevention and Punishment of the Crime of Genocide" de 28.05.1951, a CIJ, em resposta a um dos quesitos para os quais foi questionada, apresentou como normas inderrogáveis as constantes na Convenção para Prevenção e Repressão do Crime de Genocídio, porque "os princípios nos quais se fundamenta são reconhecidos pelas nações civilizadas, como obrigatórios aos Estados, independentemente de serem normas de uma Convenção internacional; ela foi concebida como uma convenção de alcance universal; sua finalidade é puramente humana e civilizadora; os contratantes não auferem nem vantagens, nem desvantagens individuais; nem interesses próprios, mas um interesse comum" SOARES, Guido Fernando Silva. Curso de direito internacional público. São Paulo: Atlas, 2002.p. 129.
} ONU. 
De maneira geral, pode-se dizer que os direitos concernentes aos migrantes fazem parte de uma reconsideração por parte dos Estados do estrangeiro "como sujeito de direito e, portanto, dotado de capacidade jurídica" (CHAPARRO, 2008, p.161). Compete, sim, ao crivo soberano do Estado dispor de quais direitos gozam os estrangeiros em um dado momento em seu espaço territorial. Contudo, é patente, conforme verificado anteriormente, que a soberania estatal sofre limitações por parte da ordem jurídica internacional. Cabe lembrar, consoante os dizeres de Alfred Verdross, que o fundamento principal dos direitos dos estrangeiros encontra-se na dignidade da pessoa humana (CHAPARRO, 2008, p.161). Disso decorre a importância do reconhecimento da aplicação das normas de direitos humanos aos estrangeiros.

\subsection{Instrumentos normativos concernentes aos mi- grantes internacionais e sua implementação}

\subsubsection{A convenção internacional sobre a proteção dos direitos de todos os trabalhadores migrantes e membros de suas familias}

Os dispositivos da DUDH aplicam-se de forma genérica a qualquer indivíduo, o que permite interpretar que também os migrantes podem se valer da proteção ali declarada. Sentindo carência de uma proteção efetiva no plano internacional, capaz de exarar obrigações específicas aos Estados no que concerne a uma categoria determinada de migrantes, em dezembro de 1990, a Assembleia Geral da ONU adotou a Convenção Internacional sobre a Proteção dos Direitos de Todos os Trabalhadores Migrantes e dos Membros das suas Famílias.

Nas palavras dos redatores dessa Convenção, a expressão “[...] 'trabalhador migrante' designa a pessoa que vai exercer, exerce ou exerceu, uma atividade remunerada num Estado de que não é nacional"(ONU, 2008, p. 3) Interessa notar que os redatores não adentraram no mérito da regularidade ou irregularidade da estada, sendo que o principal objetivo da Convenção "[...] é que todos os trabalhadores migrantes, tal como são definidos na Convenção possam gozar dos seus direitos humanos, independentemente do seu estatuto jurídico" (ONU, 2008, p.12).

A Convenção foi adotada pela Resolução 45/158 da Assembleia Geral da ONU em 18 de dezembro de 1990 e entrou em vigor em $1^{\circ}$ de julho de 2003, após a ratificação efetuada por 20 Estados. Atualmente, a Con- venção conta com 45 Estados-partes. ${ }^{16}$ Interessa notar que o artigo $3^{\circ}$ da Convenção determina não se aplicar a seu campo de abrangência pessoal, não se aplicando a:

a) Pessoas enviadas ou empregadas em organizações internacionais ou agências internacionais;

b) Pessoas enviadas ou empregadas por Estados para executar funções oficiais;

c) Pessoas enviadas pelo Estado ou em seu nome no exterior para trabalhar com programas de desenvolvimento e outros programas de cooperação, sendo que sua admissão será regulada por acordo entre os Estados envolvidos, no qual não são considerados imigrantes;

d) Estudantes ou trainees;

e) Pessoas residindo em outro país como investidores;

f) Refugiados e apátridas, a menos que tal extensão seja conferida por legislação interna; e

g) Trabalhadores marítimos em instalações em alto mar que não tenham sido admitidos para ter remuneração ou residência no Estado de emprego

De forma geral, a Convenção inclui disposições relacionadas com a prevenção das migrações irregulares, as obrigações dos migrantes e o papel dos Estados para prevenir a imigração irregular. Basicamente, os direitos enunciados são de cunho civil e político, sendo também citados alguns direitos econômicos, sociais e culturais, os quais constam em três das nove partes que conformam a Convenção, consoante será apresentado nos parágrafos seguintes.

A parte III (arts. $8^{\circ}$ a 35) apresenta os direitos humanos dos trabalhadores migrantes (genericamente considerados, ou seja, independentemente de sua situação jurídica) e dos membros de suas famílias. Dentre esses direitos, estão compreendidos liberdade de circulação (art.

${ }^{16}$ Cf.: STATUS of Treaties. Disponível em: <http:// treaties. un.org/Pages/ViewDetails.aspx? src=TREATY\&mtdsg_ no=IV-13\&chapter $=4 \&$ lang=en $>$. Acesso em: 04 mar. 2011. 
$8^{\circ}$ ), de expressão (art. 13), de pensamento, consciência ou religião (art. 12); direito à vida (art. $\left.9^{\circ}\right)$; proteção contra tortura ou tratamentos degradantes (art. 10); proibição contra escravatura ou trabalhos forçados de qualquer tipo (art. 11); direito à privacidade de vida e comunicação (art. 14); e proteção contra expropriação (art. 15).

Há também direitos que visam a preservar a liberdade e a integridade do migrante, entre os quais: a proteção contra prisão arbitrária (art. 16), a obrigatoriedade de aviso às autoridades consulares em caso de prisão (art.16, 7), garantias penais em caso de prisão (art. 17), tratamento equiparado ao dos nacionais perante tribunais (art. 18), respeito ao princípio da anterioridade da lei penal (art. 19) e o asseguramento da impossibilidade de prisão civil (art. 20). Posteriormente, apresentam-se direitos de caráter privado e decorrentes da personalidade: direito à assistência consular (art. 23), à proteção de seus documentos contra destruição arbitrária (art. 21), garantia contra expulsão coletiva (art. 22), direito de reconhecimento da personalidade jurídica (art. 24), e proteção à infância com assegurado direito de registro e nacionalidade ao filho do migrante (art. 29).

Os direitos sociais, culturais e econômicos foram contemplados nas seguintes disposições: direitos trabalhistas equiparados aos dos nacionais (art. 25), incluindo a seguridade social (art. 27), direitos coletivos de trabalho (art. 26), direito à saúde (art. 28), direito à educação (art. 30), identidade cultural (art. 31) e resguardo de suas poupanças e bens, incluindo direitos de transferência dos mesmos (art. 32).

Por fim, a Convenção apõe o dever ao Estado de imigração e ao Estado receptor de informar aos migrantes seus direitos (direito à informação das normas constantes na Convenção - art. 33), e ao migrante o dever de respeitar as leis locais e os nacionais do país receptor (art. 34).

A parte IV (arts. 36-56) indica os direitos de trabalhadores migrantes e membros de suas famílias que se encontrem com a estada regular ou documentados, compreendendo: direito à informação de seu status e permanência (art. 37), liberdade de circulação e residência (art. 39), direito de se ausentar legalmente do trabalho (art. 38), direito de sindicalização (art. 40), direitos políticos exercidos em face de seu Estado de origem (art. 41), direito de criação de instituições que irão defender seus interesses (art. 42,1), direito de serem consultados ou par- ticiparem na administração da comunidade local (art. 42, 2). Também estão presentes direitos sociais: igualdade em relação aos nacionais no que tange ao acesso à educação, à orientação, ao aperfeiçoamento e à colocação profissional, à habitação, a programas de saúde e à vida cultural (art. 43), estendendo-se tais direitos à sua família (art. 45). Cabe ressaltar que tais direitos são prerrogativas de concessão do Estado no qual se encontrem, tratando-se, portanto, de uma tentativa de incentivar políticas públicas de proteção ao indivíduo, independentemente de sua nacionalidade.

A família do migrante recebe ênfase, sendo previsto o direito à sua proteção (art. 44,1), assim como o direito de reunificação familiar (art. 44, 2), instituto pertinente aos direitos humanos que se aproveita aos estrangeiros em geral. Em caso de divórcio ou separação, é assegurada a permanência da família ou a concessão de um período razoável para que ela se retire do país (art. 50).

Igualmente, são mencionados direitos econômicos: garantia de benefícios advindos de união aduaneira (art. 46), direitos de transferir seus ganhos para o país de origem (art. 47), equiparação ao nacional para efeitos de incidência tributária (art. 48), livre escolha da atividade remunerada (art. 49, 2). Em caso de trabalhador vinculado a um contrato de trabalho específico, o fato de o contrato ter cessado não é motivo para a pessoa ter de sair do país (art. 51), direito de escolha livre do emprego (art. 52 e 53), proteção contra demissão e desemprego (art. 54), igualdades de oportunidade no emprego (art. 55).

A parte V (art. 57-63) é especialmente direcionada a tipos específicos de trabalhadores migrantes (fronteiriços, sazonais, etc.) e membros de suas famílias. O art. 57 expressamente menciona que apenas os trabalhadores com estatuto jurídico regular podem estar abrangidos por esse capítulo.

Após observar todos os dispositivos, pode-se dizer que a Convenção possui uma concepção abrangente, ${ }^{17}$ apesar de formalmente dividir a disposição dos direitos conforme a situação dos migrantes. Ressalte-se que em seu texto não se confere aos trabalhadores em situação migratória irregular o direito à regularização do seu estatuto.

\footnotetext{
${ }^{17}$ Outro ponto relevante da Convenção é o respeito ao princípio da não discriminação, o qual já é indiretamente enunciado no artigo 1 e recebe especial atenção no artigo 7.
} 
No que tange a seu conteúdo, a Convenção reforça textos anteriores de direitos humanos que tangenciam o tema dos migrantes ao tratar de outras questões específicas.

\begin{abstract}
A Convenção tem em conta as normas laborais internacionais em vigor, bem como as Convenções relativas à escravatura. Também remete para disposições da Convenção da UNESCO relativa à luta contra a discriminação no campo do ensino, Convenção Internacional sobre a Eliminação de Todas as Formas de Discriminação Racial, Pacto Internacional sobre os Direitos Civis e Políticos, Pacto Internacional sobre os Direitos Econômicos, Sociais e Culturais, Código de Conduta para os Funcionários responsáveis pela Aplicação da Lei, Convenção sobre a Eliminação de Todas as Formas de Discriminação contra as Mulheres, Convenção contra a Tortura e os Direitos da Criança, e Declaração do Quarto Congresso das Nações Unidas para a Prevenção do Crime e o Tratamento dos Delinqüentes (ONU, 2008, p.12).
\end{abstract}

A Convenção procura sistematizar os tratados citados no parágrafo anterior e relacioná-los aos migrantes. De modo geral, resume "[...] a opinião manifestada por peritos, durante mais de meio século, sobre os problemas dos trabalhadores migrantes e tem em consideração as exigências de um vasto leque de instrumentos jurídicos nacionais e internacionais" (ONU, 2008, p.12).

Alguns Estados têm relutado em ratificar essa Convenção alegando como dificuldades a sua amplitude e complexidade e as obrigações técnicas e financeiras que dela decorrem. Ademais, ela confere direitos aos migrantes irregulares, os quais não se encontram contemplados em nenhum outro tratado de direitos humanos. Embora não tenha alcançado um grande número de ratificações, a Convenção dos migrantes constitui o principal instrumento sistematizador da matéria.

Conferindo reforço às disposições da Convenção sobre os Direitos dos Trabalhadores Migrantes, a Corte Interamericana de Direitos Humanos apresenta na Opinião Consultiva 18/03 o entendimento de que os trabalhadores migrantes, da mesma forma que todos os outros, devem ter o gozo e o exercício dos direitos humanos garantidos nos Estados de residência. O Estado solicitante da opi- nião, no caso o México, ${ }^{18}$ preocupava-se com a variedade de interpretações e práticas, muitas em caráter discriminatório, dos Estados americanos sobre os direitos dos trabalhadores migrantes, mormente no que diziam respeito aos trabalhadores irregulares ou indocumentados.

A Corte, em decisão unânime, afirmou que os Estados têm a obrigação geral de respeitar e garantir os direitos fundamentais. Com esse propósito, devem adotar medidas positivas e evitar tomar iniciativas que limitem ou mitiguem um direito fundamental, suprimindo as medidas e práticas que venham restringir ou vulnerar esse direito. Afirma que o descumprimento dessas prescrições é fator suficiente para gerar responsabilidade internacional. Sustenta, ademais, que o princípio de igualdade e não discriminação possui status de ius cogens, devendo, portanto, ser respeitado tanto no âmbito interno, quanto no internacional.

Segundo a decisão, além de todos os direitos humanos, deve ser reconhecido ao migrante, independentemente de seu status migratório, o direito ao devido processo legal. No âmbito trabalhista, foi marcante o reconhecimento dos direitos aos trabalhadores migrantes, mesmo para os não documentados. Nesse sentido, o Estado tem obrigações diretas para com os trabalhadores, fiscalizando e punindo os empregadores que incorrerem na exploração desse tipo de trabalho.

\subsubsection{A Convenção contra o crime transnacional or- ganizado e seus protocolos}

A respeito do direito dos migrantes ainda há que mencionar a Convenção contra o Crime Transnacional Organizado, patrocinada pela ONU, que entrou em vigor em setembro de $2003 .{ }^{19}$ Esse texto é considerado pelos

${ }^{18}$ As normas, cuja interpretação solicitou o México à Corte, são as seguintes: os artigos 3.1 e 17 da Carta da OEA; o artigo II (Direito de igualdade ante a Lei) da Declaração Americana dos Direitos e Deveres do Homem (Declaração Americana); os artigos 1.1 (Obrigação de Respeitar os Direitos), 2 (Dever de Adotar Disposições de Direito Interno), e 24 (Igualdade ante a Lei) da Convenção Americana; os artigos 1, 2.1 e 7 da Declaração Universal dos Direitos Humanos (Declaração Universal), e os artigos 2.1, 2.2, 5.2 e 26 do Pacto Internacional de Direitos Civis e Políticos LEÃO, Renato Zerbini Ribeiro. Corte interamericana e o direito dos trabalhadores migrantes, 17/10/2003. Disponível em: <http://www.sindicatomercosul.com.br/noticia02.asp? noticia $=9131>$. Acesso em: 04 mar. 2010.

${ }^{19}$ A Convenção já ratificada também por 166 países (dados até 04.03.2012). 
especialistas como o principal instrumento para combater o crime organizado. A essa Convenção somam-se três protocolos adicionais: Protocolo Adicional à Convenção contra o Crime Organizado Transnacional para Prevenir, Reprimir e Punir o Tráfico de Pessoas e em particular de Mulheres e Crianças, ${ }^{20}$ Protocolo contra o Contrabando de Migrantes por Terra, Mar e $\mathrm{Ar}^{21}$ e o Protocolo contra a Fabricação e Tráfico Ilícitos de Armas de Fogo, das suas Peças, Componentes e Munições. 22

O histórico desses documentos está intimamente ligado à busca dos Estados para combater o crime organizado e, em 1996, uma Declaração foi adotada em Nápoles nesse sentido. A Polônia tomou as rédeas do tema e redigiu um projeto de convenção, o qual foi discutido na cidade de Varsóvia em 1998. A partir desse intento, a Assembleia Geral da ONU encarregou um comitê ad hoc de elaborar a convenção internacional contra o crime organizado e três protocolos adicionais. A sociedade civil somou-se a 120 Estados para negociar esses textos internacionais. As negociações foram finalizadas em outubro de 2000 e a AG adotou a Convenção junto com seus protocolos em novembro de $2000 .{ }^{24}$

O Protocolo Adicional à Convenção contra o Crime Organizado Transnacional para Prevenir, Reprimir e Punir o Tráfico de Pessoas e em particular de Mulheres e Crianças traz importantes pontos para os migrantes, considerando que a abordagem para o tráfico tem de ser vista sob um prisma multifacetado. Trata-se de um problema que, além de constituir um crime, toca diversos pontos: a imigração irregular de pessoas que desejam melhores condições de vida, a violação de direitos humanos que isso implica, as situações de irregularidade laboral (incluindo o tráfico de pessoas para exercício de atividade escrava) e de saúde. Esse Protocolo, de forma genérica, busca prevenir e combater o tráfico de pessoas com especial atenção a

${ }^{20}$ O Protocolo referido foi ratificado por 127 países (dados de 04.03.2012). O texto entrou em vigor em dezembro de 2003.

${ }^{21}$ O Protocolo referido foi ratificado por 129 países (dados de 04.03.2012). O texto entrou em vigor em janeiro de 2004.

${ }^{22} \mathrm{O}$ Protocolo referido foi ratificado por 90 países (dados de 04.03.2012). O texto entrou em vigor em 3 de julho de 2005.

${ }^{23}$ As informações a respeito desses documentos foram obtidas em <http://www.unodc.org/unodc/en/treaties/CTOC/signatures.html>. Acesso em: 04 mar. 2012.

${ }^{24}$ Vide a 55 ${ }^{\text {a }}$ Sessão da Assembleia Geral da ONU, 15.11.2000, A.55. PV62. mulheres e crianças, protegendo tais vítimas e promovendo cooperação entre os Estados-membros.

O Segundo Protocolo cuida do tema do contrabando de pessoas migrantes, não tendo uma abordagem tão genérica quanto o primeiro. É importante diferenciar as duas práticas codificadas pelos dois protocolos: tráfico de migrantes e tráfico de pessoas são fenômenos distintos, embora correlatos. Ambos envolvem o recrutamento e o transporte organizados por redes criminosas de pessoas. Todavia, o tráfico de pessoas envolve alguma exploração extra de caráter escuso. O fim do tráfico de migrantes é fazer com que a pessoa chegue a seu destino, desse alcance advém o lucro da atividade. Por outro lado, o tráfico de pessoas envolve o lucro com a viagem e com a exploração do trabalho da pessoa traficada no exterior.

Embora a vítima do tráfico tivesse originalmente consentido ao tráfico, é o caráter de exploração que diferencia tráfico de pessoas do tráfico de migrantes. Nesse sentido, o tráfico de migrantes assume o caráter de um crime contra a ordem e soberania do Estado.

O Segundo Protocolo criminaliza o tráfico de migrantes, mas não a migração, deixando a cargo do Estado as medidas que julgar cabíveis ao imigrante irregular. Aliás, o referido Protocolo estipula diversas medidas que os Estados devem tomar para assegurar que a vida dessas pessoas não seja posta em risco pelos "passadores".

\subsubsection{Organizações internacionais que cuidam do fenômeno das migrações internacionais}

Há uma miríade de organizações internacionais que de forma parcial e simultânea cuidam da questão das migrações internacionais.

A Organização Internacional do Trabalho (OIT), dado seu mandato internacional, especializa-se na situação dos trabalhadores, incluindo os migrantes, mas não possui qualquer capacidade operacional para observar a situação dos migrantes no terreno, o que faz com que seu trabalho seja meramente regulamentador e de alcance simbólico.

O Alto Comissariado das Nações Unidas para Refugiados (ACNUR) diz respeito à proteção dos indivíduos em condição de refugiados ou os solicitantes de refúgio (de forma específica, também se protege os retornados, reassentados, apátridas e deslocados internos). O refugiado é o migrante compelido a se mover de seu 
país de nacionalidade ou domicílio, em virtude de perseguição política, de raça, etnia, ou violação massiva de direitos humanos.

O Alto Comissariado das Nações Unidas para os Direitos Humanos (ACNUDH) colabora com os órgãos convencionais, e o mandato da Relatora Especial da ONU sobre os Direitos Humanos dos Migrantes inclui a proteção dos migrantes vítimas de contrabando e tráfico e promove a ratificação da Convenção de 1990. Essa relatoria foi criada em 1999 no sistema da ONU de proteção internacional do ser humano.

A Organização Internacional para as Migrações (OIM) não é um organismo da ONU, não obstante mantenha com ela um Acordo de Cooperação, assinado em 1996. A OIM não possui um mandato de proteção. De acordo com o preâmbulo de seu tratado constitutivo, o seu trabalho consiste em advogar pela existência de serviços de migração em nível internacional. O trabalho é entendido no sentido de vincular a migração à situação dos países em desenvolvimento e suas necessidades. Os propósitos e funções da OIM, em forma sumariada, são os seguintes:

a) fazer acordos para organizar a transferência de migrantes, refugiados, pessoas deslocadas e outros indivíduos que necessitem dos serviços de migração internacional;

b) promover serviços migratórios aos Estados ou no interesse de alguma organização internacional, tais como o treinamento e preparação para a imigração, retorno voluntário ou repatriação;

c) foro de discussão a respeito da questão das migrações; e

d) a sede da OIM é em Genebra, possuindo atualmente 146 Estados-membros, sendo o Brasil um dos membros. ${ }^{25}$

${ }^{25}$ Vide site ORGANIZACIÓN INTERNACIONAL PARA LAS MIGRACIONES. Disponível em: < http://www.iom.int/ jahia/Jahia/about-iom/lang/en>. Acesso em: 04 mar.2012.

\section{Tratamentos conferidos pelos estados às mi- grações internacionais: a questão das migra- ções irregulares}

A tendência dos Estados é de abrir as fronteiras ao que consideram parte de seus interesses: pesquisadores, turistas e investidores. Aos demais transeuntes, as portas são cerradas.

Em termos normativos, há três princípios internacionais que norteiam as migrações (MURILLO, 2008, p.27):

a) direito soberano dos Estados de adotar políticas migratórias tem limites estabelecidos por instrumentos de direitos humanos;

b)Estado deve proteger todas as pessoas sob sua jurisdição, independentemente de sua condição migratória;

c) em caso de perseguição, a pessoa tem direito de solicitar refúgio (art. XIV da DUDH em 1948).

É tarefa árdua garantir a respeitabilidade de tais princípios. E a ela, soma-se outro desafio: a maior parte das migrações atuais é irregular. Alguns trabalhadores, confrontados com situações críticas no mercado de trabalho de seu país de origem, apostam na irregularidade da permanência no estrangeiro como meio de tentar melhorar a renda própria e da família.

O imigrante irregular é um termo utilizado para descrever uma série de fenômenos diferentes que envolvem pessoas que entram ou ficam num país do qual não são cidadãos e não possuem permissão para ficar de acordo com as leis nacionais. Incluídos nesse conceito estão os migrantes com estada irregular (seja de entrada ou permanência) e as pessoas que solicitaram refúgio, mas que, uma vez tendo seu pedido denegado pelos órgãos estatais competentes, não obedecem à ordem de sair do país ou não se regularizam. Então, são sinônimos os seguintes termos: migração não autorizada, não documentada ou ilegal (a definição do status irregular consta no art. $5^{\circ}$ da Convenção sobre Direitos dos Migrantes). Lembrando que o termo imigração ilegal foi banido dos meios acadêmicos, especialmente por parte dos estudiosos de direitos humanos, considerando sua luta para fazer reconhecer o óbvio: imigrar não é crime. Criminosas são, sim, as redes 
que lucram com o contrabando de migrantes e o tráfico de seres humanos.

Quão maior for o controle sobre as fronteiras, mais fácil se torna construir o conceito de imigração irregular. Isso é claramente visto na Europa, ao passo que na África, espaço de fronteiras porosas, as diferentes comunidades nômades e etnias mesclam-se por entre as linhas divisórias artificiais criadas pelo colonizador. Ademais, é fato que, nesse continente, muitas pessoas padecem de documentação para provar seu local de nascimento ou mesmo a própria nacionalidade. Os fluxos migratórios africanos são justamente os de tipo misto: em função de diversos infortúnios, estão presentes muitas razões para os africanos partirem de seus locais de origem.

Mas, qual seria a razão de tentativas tão arriscadas para migrar? Considerando esse pensamento, é patente que os Estados devem "[...] criar um contexto no qual as pessoas migrem por opção, de forma segura e legal, em vez de irregularmente e por concluírem que não têm nenhuma melhor alternativa" (GLOBAL COMMISSION ON INTERNATIONAL MIGRATION, 2005, p.35). Portanto, não se deve presumir que sempre está presente o elemento volitivo daquele que migra de forma irregular.

Por definição, as vítimas do tráfico de seres humanos não são livres de escolher as atividades em que se envolvem. São freqüentemente forçadas a realizar trabalhos mal pagos, inseguros e degradantes dos quais não têm possibilidade de escapar e pelos quais recebem uma remuneração insignificante, ou não recebem mesmo nada (GLOBAL COMMISSION ON INTERNATIONAL MIGRATION, 2005, p.35).

Para as mulheres e crianças, a situação é ainda mais grave; quase sempre as mulheres ficam em situação irregular, vez que lhes é mais difícil concorrer para os empregos regulares. A seu turno, as crianças, separadas de seus pais, ficam vulneráveis, podendo estar sujeitas a diversas situações de risco, como escravatura sexual ou tráfico de órgãos. Some-se a isso a enorme possibilidade de essas crianças tornarem-se apátridas, em função de um conflito negativo de leis.

Os migrantes em situação irregular evitam frequentemente procurar ajuda junto a autoridades por recearem ser detidos e deportados. Por isso que muitas irregularidades e violações de direitos humanos que lhes são cometidas ficam impunes.
A abordagem dos Estados para o combate às imigrações irregulares está equivocada. Uma ação repressiva de controle de fronteiras e punição das redes de tráfico não deve constituir o único foco. Regras restritivas de imigração podem servir "[...] de incentivo à atuação de máfias internacionais que se especializaram no tráfico de pessoas e de imigrantes" (BARRETO, 2007, p.30) ou aumentar as célebres tentativas arriscadas de imigração irregular. "Ao procurarem atingir os seus objetivos legítimos de controlo fronteiriço, os Estados não podem deixar de respeitar as suas obrigações em termos de direitos humanos" (GLOBAL COMMISSION ON INTERNATIONAL MIGRATION, 2005, p. 34).

De fato, os migrantes irregulares têm seu fluxo incentivado por certos setores da economia que diretamente dependem deles: são aceitos porque o mercado de trabalho formal está muito regulamentado e oneroso para o empregador. Acabam as autoridades governamentais por fechar os olhos a setores que de forma notória valem-se desse tipo de mão de obra. Incremento de fiscalização é necessário, assim como a elaboração de políticas públicas que permitam o correto desenvolvimento das migrações regulares. É verificado que programas regulares de migração minimizam esse problema.

os programas de migração regular podem reforçar a confiança da opinião pública na capacidade dos Estados admitirem migrantes no seu território com base nas necessidades do mercado de trabalho. Programas deste teor também ajudam a criar uma imagem mais positiva e a promover uma maior aceitação das migrações internacionais junto da opinião pública (GLOBAL COMMISSION ON INTERNATIONAL MIGRATION, 2005, p. 36).

Em relação às pessoas que já se encontram no território de forma irregular, os Estados costumam aplicar duas opções - o retorno, nem sempre voluntário, ou a regularização. A opção pelo processo de regularização é louvável, uma vez que oferece um estatuto legal aos migrantes irregulares que já se encontram, muitas vezes, adaptados ao país, estando social e economicamente inseridos.

O Estado receptor tem papel fundamental no processo de inserção. É necessária uma atuação positiva, seja por meio de políticas públicas que incentivem a contratação e a diversidade, de permissivos à participação na vida 
civil e política ou de acesso aos serviços sociais. ${ }^{26}$ Do mesmo modo, as pessoas da administração pública que lidam com migrantes necessitam receber a formação adequada para que compreendam o seu universo.

\subsection{Os processos de integração econômica e sua de- sarmonia com o conceito de livre circulação de pessoas}

Cumpre no momento analisar o impacto das migrações nos blocos de integração econômica. Intensificados pelos fluxos da globalização da década de 1990, os processos de integração negam-se a conferir a mesma abertura à livre circulação de pessoas que aquela conferida a bens e mercadorias. Em um primeiro momento, será analisado o bloco mais tradicional e amplo, a União Europeia, e, em um segundo momento, o Mercosul, por sua relação regional com o Brasil.

\subsubsection{A União Europeia e as recentes discussões a res- peito das migrações internacionais}

A maioria dos países receptores de migrantes está restringindo a entrada, muito embora a Austrália, Canadá e Estados Unidos da América, destinos tradicionais, ainda continuam a aceitar migrantes a título definitivo e com objetivo de obterem a cidadania, tendo para isso procedimentos institucionalizados. Dependendo do momento histórico, as migrações podem ser consideradas benéficas ou prejudiciais ao país que recebe os fluxos. Com o aumento recente dos fluxos temporários, ficou em realce o maior relacionamento entre os países envolvidos no processo de imigração. No passado, como os meios de transporte não permitiam, as pessoas faziam uma migração em caráter definitivo. Atualmente, a temporalidade é característica, uma vez que as pessoas tendem a ficar determinado período até atingir um montante financeiro que lhe interesse e retornar a seu país de origem.

Outrora território de emigrantes a povoar outras esferas do globo, a Europa se tornou um espaço com Estados prósperos e cerrados na fortificação de suas fronteiras, em que se testemunha um aumento da xenofobia e, consequentemente, da limitação aos fluxos migratórios.

\footnotetext{
${ }^{26}$ Os Estados têm que cumprir a sua obrigação de providenciar aos migrantes irregulares e suas famílias os serviços básicos, tais como cuidados essenciais à saúde e a educação das crianças.
}

Por exemplo, em maio de 2008, o Primeiro Ministro italiano, Sílvio Berlusconi, anunciou medidas que limitavam o ingresso de estrangeiros no país e facilitariam a expulsão dos irregulares, transformando a imigração clandestina em crime. Em território italiano, haverá maior facilidade para detenção de imigrantes irregulares e óbices para transferências financeiras. Ademais, poderá ser solicitado teste de DNA para comprovação de razão para pedidos de reunificação familiar. Os prazos de detenção dos imigrantes irregulares foram estendidos de dois para dezoito meses. Há também a previsão de agravantes penais para estrangeiros irregulares que forem condenados por crimes comuns.

A ode contrária aos estrangeiros não se restringe aos que não fazem parte da comunhão de "irmãos europeus", até para aquele que possui cidadania europeia será necessário comprovar renda legal e suficiente, demonstrando que não será um estorvo ao governo italiano. A população deu apoio às medidas em razão da onda de violência recente, colocando os estrangeiros como responsáveis, especialmente romenos e ciganos.

A medida mais criticada foi a consideração da imigração irregular como um crime, não anistiando nem os irregulares que possuam trabalhos. Alguns governos, mesmo europeus, demonstraram indignação com tal medida. Mesmo assim, pode-se dizer que uma onda contrária às migrações toma conta do continente e talvez se intensifique com a crise econômica. Já é notícia que a Espanha para o exterior, apresenta o maior índice de desemprego após a anunciada crise que se fez nesse fim de ano.

A contrario sensu, a discussão a respeito da matéria em 2007 indicava que se deveria buscar uma nova política de imigração que favorecesse a migração regular e incrementar a busca pelo fim da imigração irregular e das redes de tráfico internacional de pessoas. Interessante que documentos oficiais da época apontam para a urgente elaboração de uma política de imigração que leve em consideração os interesses dos migrantes e a possibilidade de sua evolução no seio da sociedade. Foram elaborados princípios comuns de ação que envolvem a elaboração de regras claras e condições para a imigração, princípios de transparência, gestão integrada de fronteiras, parcerias com países terceiros para a elaboração de parcerias de migração regular e a construção de políticas de inclusão, ou, quando for o caso, de regresso, que sejam duradouras e eficazes. 
De forma paradoxal, o primeiro passo para o estabelecimento de uma política de imigração acabou sendo imensamente criticado. A famosa "Diretiva do Retorno" acabou sendo criticada no ano passado e recebeu aprovação controversa no Parlamento Europeu. De acordo com essa norma, os governos poderiam deter imigrantes ilegais por até dezoito meses. Em tese, a ideia da norma é incentivar o retorno voluntário e quando tal não ocorresse, o Estado poderia deter a pessoa a ser deportada. Muito criticada pelas entidades de direitos humanos e partidos de esquerda do Parlamento, a Diretiva foi um intento de harmonizar as leis a respeito da matéria entre os Estados da União Europeia. "O texto impede que os Estados-membros apliquem normas menos favoráveis do que as previstas nesta diretiva, dando-lhe simultaneamente a liberdade de aplicar normas mais favoráveis" (PARLAMENTO EUROPEU, 2008, p.2).

De acordo com a norma, o estrangeiro irregular terá de 7 a 30 dias para sair do país. Não o fazendo, poderá ficar sujeito à detenção de seis meses, prorrogável por mais doze meses. A decisão de detenção poderá ser tomada por autoridades administrativas ou judiciais, sendo que, se for tomada pelas primeiras, ficam sujeitas a controle jurisdicional. É assegurado também o direito de assistência a um advogado (até mesmo defensores públicos) e serviço de intérprete, quando necessário. Uma das partes mais sensíveis da diretiva é a possibilidade de detenção de menores desacompanhados. Em tese, devem lhes ser assegurado todos os direitos humanos, mas muitos duvidam que isso seja executado. Os Estados dispõem de 36 meses para transpor a diretiva para suas legislações internas, fazendo algo que ativistas de direitos humanos consideram um retrocesso.

Além da Diretiva de retorno, em outubro foi aprovado na União Europeia o Pacto Europeu sobre Imigração e Asilo. O objetivo de tal pacto é ter regras mais rígidas de imigração e estabelecer uma política comum de asilo. A inspiração foi do presidente francês Nicolas Sarkozy- no intuito de extinguir as regularizações coletivas.

Desde $1^{\circ}$ de janeiro, a pedido do Presidente da República, ele visitou os vinte e seis outros Países-membros, que manifestaram, em sua totalidade, interesse por sua iniciativa. A recepção foi logicamente mais atenta nos quatro outros países nos quais, juntamente com a França, concentram-se $80 \%$ dos fluxos migratórios para a Europa - Itália, Espanha, Grã-Bretanha e Alemanha (HORTEFEUX, 2006).
No texto, é privilegiada a imigração laboral e familiar; lutando-se contra a clandestinidade, foi enfatizado o controle de fronteiras e a repatriação dos irregulares. O Brasil apresentou duras críticas ao texto em nota oficial. ${ }^{27}$

\subsubsection{O Brasil e o Mercosul no contexto das migrações internacionais}

No discurso oficial, a conjuntura política regional aponta para o fortalecimento do Mercado Comum do Sul (Mercosul), com o avanço de políticas direcionadas àqueles que se movimentam entre os Estados-membros, ${ }^{28}$ seja por motivos de mudança de residência ou permanências temporárias. No continente latino-americano, os deslocamentos populacionais são antigos, envolvendo o recebimento de fluxos intercontinentais.

Sem dúvida, os movimentos de população têm sido uma constante na história da humanidade, já fossem como consequência de mudanças climáticas, crescimentos demográficos ou necessidades econômicas. Porém, na atualidade, os fluxos migratórios adquirem uma especial relevância devido ao seu alcance global (RIPOLI, 2009, p. 2).

Em trabalhos recentes, são apontadas novas tendências dos fluxos migratórios, que indicam uma redução da imigração ultramar, pari passu a um incremento da migração intrarregional. No que tange aos cidadãos dos países em desenvolvimento, seu destino mais atrativo tem sido a Espanha (RIPOLI, 2009, p. 5). O Brasil está entre os vinte primeiros países que enviam imigrantes para a Espanha (RIPOLI, 2009, p. 7) e a população emigrante possui por característica ser jovem e em idade laboral.

Além do movimento pendular sul-norte, é verificado um aumento dos fluxos intrarregionais, em razão, por exemplo, de atividades sazonais realizadas em regiões fronteiriças. Igualmente, é verificado que esses fluxos têm sido sensíveis às situações de expansão ou retração econômica, da mesma forma que a situações de violência ocorridas no país de emigração. Migrações, assim como os deslocamentos forçados, intensificaram-se a partir da década de 1990 na região latino-americana, por razões de disparidades nas condições de vida entre o país de origem e aquele de destino dos migrantes.

${ }^{27}$ Cf. Nota MRE n. 520 de 26.09.2008.

${ }^{28}$ Estados-membros: Brasil, Argentina, Paraguai e Uruguai. A Venezuela ainda se encontra em processo de adesão. 
Na América Latina, historicamente, o processo de desenvolvimento foi gerado em parte pela imigração estrangeira (GREGORI, 2007, p.17). Especialmente após a II Guerra Mundial, a imigração transatlântica recebeu uma nova característica: eram trabalhadores qualificados. Desses, a América Latina absorveu 338 mil, os quais foram subvencionados por uma comissão intergovernamental.

A década de 1990 foi marcada por oscilações de caráter econômico e político. Via de consequência, apenas a Venezuela apresentou ligeiro aumento do fluxo de imigrantes, sendo a maioria das pessoas de nacionalidade colombiana. De forma geral, os colombianos compõem um número sensível de imigrantes e refugiados para países da América Latina.

No que tange ao Brasil, pode ser salientado que as últimas décadas do século XX trouxeram à tona a questão das migrações internacionais, emergindo como importante questão demográfica. É estimado que mais de dois milhões de pessoas tenham deixado o país nesse período, ou seja, houve um aumento dos fluxos migratórios vindos ao Brasil. O novo processo imigratório que envolve o Brasil é seguido pela entrada de estrangeiros, especialmente provenientes dos Estados Unidos da América, países da América do Sul e Central, além da África. É de se salientar que em torno de $40 \%$ possuem a nacionalidade de Estados que são membros plenos do Mercosul, ou associados. Esse fenômeno não é recente e vem se manifestando desde a década de 1970. "A permeabilidade das fronteiras que integram os países da América Latina, num contexto de integração econômica regional, vem contribuindo para a intensificação dos deslocamentos populacionais de tipo fronteiriço" (PATARRA; BAENINGER, 2004, p. 43).

Dos trabalhadores que migram para o Brasil, a maior parte possui baixo grau de escolaridade. Os de maior grau de instrução, vulgo trabalhadores globais, provêm da Argentina, ao passo que os paraguaios possuem menor escolaridade. No momento em que se estabelecem na economia local, os uruguaios escolhem o comércio e atividades financeiras; os argentinos e chilenos, as atividades financeiras, de indústria de transformação, educação e comércio. Os bolivianos dedicam-se ao setor industrial, e os peruanos, ao comércio, à educação e à saúde. Em 2005, o Brasil celebrou com a Bolívia um acor do por troca de notas para regularização de imigrantes bolivianos com estada irregular ${ }^{29}$

Por sua vez, o Mercosul tem tentado legislar no sentido de permitir a facilitação de circulação de pessoas, além de mercadorias. Como exemplo, as normativas MERCOSUL/CMC/DEC No44/00 e MERCOSUL/CMC/ DEC No45/00 dispõem a respeito de dispensa de tradução de documentos administrativos para efeitos de imigração, envolvendo os Estados-partes do Mercosul e a Bolívia e o Chile. Em janeiro de 2009, o Brasil promulgou o Decreto no 6.729, de 12 de janeiro de 2009, publicado no Diário Oficial da União de 13 de janeiro de 2009, que tem por tema o Protocolo de Integração Educativa e Reconhecimento de Certificados e Estudos de Nível Fundamental e Médio Não Técnico entre os Estados- partes do Mercosul, Bolívia e Chile, assinado em Brasília, em 5 de dezembro de 2002. Além desse Protocolo, há ainda dois outros acordos a respeito de livre residência: o Acordo sobre Residência para Nacionais dos Estados do Mercosul (em vigor entre Brasil e Argentina $)^{30}$ e o Acordo sobre Residência para Nacionais dos Estados que fazem partes do Mercosul, Bolívia e Chile (ratificado no Brasil pelo Decreto 6.975 de 07 de outubro de 2009 e entrou em vigor internacionalmente para o Brasil em 28 de julho de 2009).

\section{Conclusão}

Atualmente é frequente identificar pessoas que possuam dupla nacionalidade, e que se identifiquem com mais de uma cultura ou dividam o seu tempo trabalhando em mais que um país. Esse é o quadro ideal das pessoas que migram por opção. O desafio aos Estados é conseguir fazer com que essa seja a regra e não que, por usufruírem de baixos níveis de segurança ou de meios de subsistência no seu país de origem, as pessoas arrisquem suas vidas para migrar, sem garantia alguma, uma vez atingido o Estado visado. É muito provável que com a redução dos níveis de pobreza e um maior incremento do respeito aos direitos humanos, haverá uma natural redução das mi-

\footnotetext{
${ }^{29}$ Vide texto do tratado simplificado no site da Divisão de Atos Internacionais do Itamaraty: <http://www2.mre.gov.br/ dai/b_boli_231_5571.htm>. Acesso em: 12 maio 2008.

${ }^{30}$ Através de uma Portaria Interministerial de 28 de agosto de 2006, foi externado que Brasil e Argentina, países do Mercosul, os quais ratificaram esse acordo, decidiram, por Troca de Notas, permitir que o tratado estivesse em vigor apenas entre os dois países a partir de 30 de novembro de 2005.
} 
grações internacionais. Todavia, enquanto essa situação ideal não se afigura, é preciso que soluções de respeito aos direitos dos migrantes sejam buscadas em instrumentos já existentes ou mesmo trabalhadas no sentido de se criarem normas específicas.

Por certo, o incentivo à migração regular é o caminho. Da parte dos Estados de emigração, pode-se trabalhar no sentido de promover cursos de orientação e formação aos migrantes regulares, antes da sua partida para que conheçam melhor os seus direitos e obrigações. Nesse sentido, é louvável a prática de firmar tratados internacionais bilaterais determinando a destinação e condições dessa migração. Os Estados de origem igualmente podem fiscalizar e cuidar para que redes de tráfico de pessoas não atuem em sua jurisdição. Por sua vez, o pessoal consular também pode se dedicar a um trabalho de monitoramento da situação dos migrantes (regulares ou irregulares) no país de destino, fazendo-se cumprir as normas de proteção de direitos humanos.

No que tange aos países receptores, cabe uma melhora nas estruturas institucionais dos Estados, orientando de forma mais adequada os profissionais que lidam diretamente com imigrantes, além da promoção de um trabalho conjunto para coibir as redes transnacionais de tráfico. $\mathrm{O}$ trabalho a ser realizado deve ser conjunto, com o envolvimento da sociedade civil, de modo a auxiliar a cooperação dos Estados para a produção e execução de políticas públicas eficazes.

Os direcionamentos básicos a uma política de migração regulamentada e bem direcionada devem se pautar no seguinte:

a) migrantes regulares informados de seus direitos e condições de emprego;

b)respeito a salário digno, horas de trabalho, cuidados de saúde e outras garantias;

c) possibilidade de transferência de emprego;

d) igualdade de gênero;

e) identificação e punição aos Estados que desrespeitem as garantias internacionais que beneficiam os migrantes;

f) processar empregadores que contratem mão de obra irregular; g) licenciar e regulamentar as atividades dos intermediários envolvidos na contratação de migrantes;

h) conceder vistos para os migrantes temporários, para que eles possam visitar a família, o que permite a manutenção de contato e um provável retorno;

i) estabelecer políticas de seguridade social integrada;

j) migração espontânea, ou seja, redução dos fatores que levam o indivíduo a migrar;

k)política de migrações internacionais devem integrar estratégias não somente nacionais, mas regionais e globais;

1) jamais penalizar o indivíduo que migra irregularmente;

m) garantia de integração com a sociedade local;

n) reforço no quadro normativo de proteção aos migrantes: incentivo à ratificação das convenções existentes; e

o) relacionar a questão das migrações a outras temáticas internacionais importantes, tais como desenvolvimento e comércio.

Os migrantes trazem enorme legado humano ao local no qual se instalam. Ademais, as migrações ajudam a limitar o nível de desemprego e subemprego nos países que têm um excesso de oferta de mão de obra, auxiliando países com envelhecimento de sua população a receber numerário. Contudo, por vezes, os melhores cérebros abandonam os países em desenvolvimento, os quais necessitam de políticas de incentivo à pesquisa e tecnologia de ponta para conseguir reter seus cidadãos.

Por certo, o maior desafio a respeito das migrações foi levantado pela Comissão de Especialistas responsável pela preparação do Relatório sobre Migrações: é necessário formular políticas que minimizem o impacto negativo das imigrações e maximizem o positivo. E essa questão não pode ser tratada de forma isolada, tampouco com medidas duras de repressão aos irregulares.

De acordo com Jacques Maritain (MARITAIN, 1982 apud TRINDADE, 2008, p.55), a humanidade so- 
mente alcançará verdadeiro progresso quando avançar no que diz respeito à emancipação humana. Aproveitando esse pensamento, é certo que o mundo irá se beneficiar com a liberalização regulamentada da imigração.

\section{Referências}

BARRETO, Luiz Paulo Teles. Discurso da Delegação Brasileira no Diálogo de Alto Nível das Nações Unidas sobre Migração e Desenvolvimento. Caderno de Debates Refúgio, Migrações e Cidadania, Brasília, v. 2, n. 2, p. 3558, 2007.

BENEVIDES, Maria Victoria. Cidadania e direitos humanos. Disponível em: <http://www.iea.usp.br/artigos/ benevidescidadaniaedireitos humanos.pdf $>$. Acesso em: 23 fev. 2010.

BROWN, Stephen. Operação contra imigração ilegal prende 383 na Itália. Disponível em: http://noticias.uol. com.br/ultnot/reuters/2 008/05/15/ult27u65981.jhtm. Acesso em: 15 maio 2008.

CASTRO, Mary Garcia. Migração internacional: transpassando fronteiras do nacional ao individual. Caderno de Debates Refúgio, Migrações e Cidadania, Brasília v. 2, n. 2, p. 69-75, 2007.

CHAPARRO, Verônica Zárate. Condição jurídica do estrangeiro. In: SANTOS, Carlos Eduardo Martins de (Coord.). Curso de direito internacional privado. Rio de Janeiro: Maria Augusta Delgado, 2008.

COMISSAO DAS COMUNIDADES EUROPEIAS. Comunicação da Comissão ao Parlamento Europeu, ao Conselho, ao Comitê Econômico e Social Europeu e ao Comitê das Regiões: uma política comum de imigração para a Europa: princípios, ações e instrumentos. Bruxelas: Comissão das Comunidades Europeias, 2008.

COMITE DE REGIOES DA UNIAO EUROPEIA. Parecer do Comitê de Regiões da União Europeia: uma perspectiva global da migração: o desenvolvimento de uma política europeia de imigração laboral e sua inserção nas relações com os países terceiros. (2008/C 257/04). Jornal Oficial da União Europeia, Bruxelas, p 20-25, 9 out. 2008.

DOWSETT, Sonya. Espanha repreende Itália por tratamento a imigrantes. Disponível em: <http://br.rss. news.yahoo.com/s/reuters/08 0516/mundo/mundo_ espanha_italia_imigracao_pol_1 $>$. Acesso em: 16 maio 2008.
DÜVELL, Franck. Questioning conventional migration concepts: the case of transit migration. Disponivel em: $<$ http://www.compas.ox.ac.uk/publications/papers/ 2006-06-21-Duvell-Budapest.pdf $>$. Acesso em: 27 jul. 2008.

FERREIRA FILHO, Manoel Gonçalves. Direitos humanos fundamentais. São Paulo: Saraiva, 2006.

GLOBAL COMMISSION ON INTERNATIONAL MIGRATION. Migration in an interconnected world: new directions for action. 2005. Disponível em: <http://www. gcim.org/en/finalreport.html>. Acesso em: 28 maio 2008.

GREGORI, José. Refugiados e imigrantes: uma abordagem de direitos humanos. Caderno de Debates Refúgio, Migrações e Cidadania, Brasília, v. 2, n. 2, p. 1527, 2007.

HAKIM, Abdul; CORR, Patrick; FARROW, Justin. International migration: conceptual and measurement puzzles. Disponível em: <http://www.apa.org.au/ upload/2004-6C_Hakim.pdf>. Acesso em: 27 maio 2008.

HORTEFEUX, Brice. Pacto europeu sobre a imigração $e$ o asilo: audiência do ministro francês da Imigração, Integração, Identidade Nacional e do Desenvolvimento Solidário, perante a delegação para a União Europeia da Assembleia Nacional Francesa. Paris, 23 de julho de 2008. Disponível em: <http://www.ambafrance.org.br/abr/ atualidades/diplomacia/pol_diplomat569.htm>. Acesso em 24 jan. 2009.

ITÁLIA adotará medidas firmes, mas não racistas contra imigração. Disponível em: <http://noticias.uol.com.br/ ultnot/afp/20 08/05/12/ult34u2049 70.jhtm>. Acesso em: 12 maio 2008.

LEÃO, Renato Zerbini Ribeiro. Corte interamericana e o direito dos trabalhadores migrante. Disponível em: $<$ http://www.sindicatomercosul.com.br/noticia02. asp?noticia=9131>. Acesso em: 04 mar. 2010.

LÓPES-CIFUENTES, Javier. Apresentação: os 60 anos da Declaração Universal dos Direitos Humanos e sua relevância para migrantes e refugiados. Caderno de Debates Refúgio, Migrações e Cidadania, Brasília, v. 3, n. 3, p. 7-11, 2008.

MARINUCCI, Roberto; MILESI, Rosita. Migrantes e refugiados: por uma cidadania universal. Caderno de Debates Refúgio, Migrações e Cidadania, Brasília, v. 1, n. 1, p. 53-80, 2006.

MILESI, Rosita. Por uma nova lei de migrações: a perspectiva dos direitos humanos. Caderno de Debates Refúgio, Migrações e Cidadania, Brasília v. 2, n. 2, p. 7796, 2007. 
MORAES, Alexandre de. Direitos humanos fundamentais. São Paulo: Atlas, 2005.

MURILLO, Juan Carlos. A proteção internacional dos refugiados na América Latina e o tratamento dos fluxos migratórios mistos. Caderno de Debates Refúgio, Migrações e Cidadania, Brasília, v. 3, n. 3, p. 25-30, 2008.

NEW DELHI ONLINE. Migration Doubled To $200 \mathrm{Mn}$ In 30 Years. Disponível em: <http://www.gcim.org/mm/ File/BS \%20Migration\%20Doubled\%20to\%20200\%20 Mn\%20in\%2030 \%20Years(4).pdf>. Acesso em: 16 nov. 2008.

O'ROURKE, Kevin H.; SINNOTT, Richard. Migration flows: Political economy of migration and the empirical challenges. Disponível em: <http://www.tcd.ie/ Economics/TEP/2003_papers/TEPNo6KOR23.pdf > Acesso em: 11 ago. 2008.

OLLUS, Natalia. Protocol against the smuggling of migrants by land, air and sea, supplementing the United Nations convention against transnational organized crime: a tool for criminal justice personnel. Disponível em: $<$ http://www.ungift.org/docs/ungift/pdf/knowledge/ unafei_analysis.pdf> Acesso em: 19 jan. 2009.

OLLUS, Natalia. The United Nations Protocol to prevent, suppress and punish trafficking in persons, especially women and children: a tool for criminal justice personnel. Disponível em: <http://www.ungift.org/docs/ungift/pdf/ knowledge/unafei_analysis.pdf $>$. Acesso em: 19 jan. 2009.

ORGANIZAÇÃO DAS NAÇÕES UNIDAS. Direitos humanos: os direitos dos trabalhadores migrantes. Série das Nações Unidas n. 24. Disponível em: <http://www. december18.net/ UNconventionPortugese.pdf $>$. Acesso em:15 ago. 2008.

ORGANIZACIÓN INTERNACIONAL PARA LAS MIGRACIONES. Disponível em: < http://www.iom.int/ jahia/Jahia/about-iom/lang/en>. Acesso em: 04 mar.2012.

PARLAMENTO EUROPEU. Imigração: a diretiva do retorno. Dossier Focus. Disponível em: http://snig.igeo. pt/Inspire/documentos/arquivo/INSPIRE Directiva.pdf. Acesso em: 25 jun. 2008.

PATARRA, Neide Lopes; BAENINGER, Rosana. Migrações internacionais, globalização e blocos de integração econômica- Brasil no Mercosul. Disponível em: $<$ http://www.abep.nepo.unicamp.br /site_eventos_alap/ PDF/ALAP2004_244.pdf $>$. Acesso em: 24 maio 2008.

PIOVESAN, Flávia. Direitos humanos e o direito constitucional internacional. São Paulo: Saraiva, 2008.
PIOVESAN, Flávia. Temas de direitos humanos. São Paulo: Max Limonad, 1998.

REIS, Rossana Rocha. Soberania, direitos humanos e migrações internacionais. RBCS, São Paulo, v. 19, n. 55, p. 149-164, jun., 2004.

RIPOLI, Erika Masanet. O Brasil e a Espanha na dinâmica das migrações internacionais: um breve panorama da situação dos emigrantes brasileiros na Espanha. Disponível em: <http://www.abep.nepo.unicamp.br/ encontro2006/docspdf/ABEP2006_499.pdf>. Acesso em: 23 jan. 2009.

RUHS, Martin; ANDERSON, Bridget. Semi-compliance in the migrant labour market. Disponível em: <http:// www.esrcsocietytoday.ac.uk /ESRCInfoCentre/Images/ Anderson\%20-\%20society_tcm6-24965.pdf>. Acesso em: 27 jul. 2008.

SABATES-WHEELER, Rachel; WAITE, Myrtha. Migration and social protection: a concept paper. Disponível em: <http://www.migrationdrc.org/ publications/working_papers/WP-T2.pdf $>$. Acesso em: 27 jul. 2008.

SOARES, Guido Fernando Silva. Curso de direito internacional público. São Paulo: Atlas, 2002.

SOUCHAUD, Sylvain; CARMO, Roberto Luiz do; FUSCO, Wilson. Mobilidade populacional e migração no Mercosul: a fronteira do Brasil com Bolívia e Paraguai. Teoria \& pesquisa, Brasília, v. 16, n. 01, , jan./jun. 2007. Disponível em: <http://hal.archives-ouvertes.fr/ docs/00/22/15/02/PDF /23_Teoria_Pesquisa_2007.pdf> Acesso em: 23 jan. 2009.

SPRANDEL, Márcia Anita. A 'questão migratória' como objeto de reflexão. Caderno de Debates Refúgio, Migrações e Cidadania, Brasília, v. 2, n. 2, p. 35-49, 2007.

TRINDADE, Antônio Augusto Cançado. Deslocados e a proteção dos migrantes na legislação internacional dos Direitos Humanos. Caderno de Debates Refúgio, Migrações e Cidadania, Brasília, v. 3, n. 3, p. 53- 93, 2008.

VARESE, Luis. O futuro da cidadania, do refúgio e da migração em debate. Caderno de Debates Refúgio, Migrações e Cidadania, Brasília v. 2, n. 2, p. 7 - 13, 2007.

VARESE, Luis.; ARMITAGE, Alanna; BOLDUC, Kim. Migrações, refúgio e direitos humanos no século 21. Correio Brasiliense, Brasília, 04. nov. 2008. Disponível em: $<$ http://www.direitos.org.br /index2.php ?option=com content\&do_pdf $=1 \& \mathrm{did}=2119>$. Acesso em: 25. maio 2008. 
VLAHOU, Assimina. Governo da Itália torna imigração clandestina crime. Disponível em: <http://www.bbc. co.uk/portuguese/reporterbbc/story /2008/05/080521_ berlusconiseguranca_av_ac.shtml $>$. Acesso em: 22 maio 2008. 